\title{
Cow raising in the Mekong Delta - The current status of waste treatment and risk of greenhouse gas emissions
}

\author{
Chăn nuôi bò ở đồng bằng sông Cửu long - Hiện trạng xử lý chất thải và nguy cơ phát thải khí \\ gây hiệu ứng nhà kính
}

\author{
NGUYEN Le Phuong ${ }^{1}$; NGUYEN Hong Tam ${ }^{2}$; THACH Si Nuo ${ }^{1,2}$; NGUYEN Vo Chau Ngan ${ }^{2}$. \\ ${ }^{1}$ Hau Giang Industrial Zones Authority, Hau Giang province, Vietnam; ${ }^{2}$ College of Environment and Natural Resources, Can Tho University, 3-2 street, \\ Can Tho city, Vietnam
}

\begin{abstract}
This study was aimed to assess the status of waste treatment for cow raising at small farm households in Can Tho, Tra Vinh, Soc Trang, and Hau Giang. The interview of 120 cow farmer households indicated that local farmers normally treat their waste by sun-drying, storing in ponds, discharging directly into rivers, or applying to anaerobic biogas. The farmers select ways to treat cow excrement according to seasons of the year: in the dry season cow waste is mostly sun-dried for sale (76.7\%); stored for use (10\%), untreated (7.5\%) or applied to biogas plants (5.8\%); however, in the rainy season most of the farmers leave the waste untreated $(94.2 \%)$, except for those owning biogas tanks. Biogas treatment is applied mainly by dairy cow-raising households, accounting for $85.7 \%$ of biogas users. The cow farmer households have limited knowledge about biogas application; $23.3 \%$ of the interviewed farmers knew about biogas technology; $47.5 \%$ had little knowledge about this technology, however, $29.2 \%$ of the selected persons had no idea about biogas technology. Based on the quantity of beef cattle herds in the surveyed areas, it is estimated that $\mathrm{CH}_{4}$ gas emissions account for around 252.3 tons, 61.4 tons, 8.2 tons, and 2.5 tons in Soc Trang, Tra Vinh, Can Tho, and Hau Giang, respectively.
\end{abstract}

\begin{abstract}
Nghiên cứu này nhằm đánh giá hiện trạng xử lý chất thải tại các hộ chăn nuôi bò ở thành phố Cần Thơ và các tỉnh Trà Vinh, Sóc Trăng, Hậu Giang. Tổng số 120 hộ chăn nuôi đã được phỏng vấn cho thấy có 4 phương pháp xử lý chính để xử lý chất thải chăn nuôi phát sinh: ủ yếm khí (biogas), phơi khô và bán, trữ lại trong ao để sử dụng, và không xử lý. Tùy theo thời điểm trong năm người dân sẽ thay đổi cách thức xử lý chất thải chăn nuôi bò: vào mùa khô có nhiều nắng chủ yếu người dân phơi khô để bán (76,7\%), để lại và sử dụng (10\%), dùng để ủ biogas (5,8\%), và không xử lý (7,5\%); tuy nhiên vào mùa mưa hầu hết các hộ dân không xử lý chất thải chăn nuôi (94,2\%), chỉ trừ những hộ dân đã có hầm ủ biogas để xử lý. Xử lý chất thải chăn nuôi bằng công nghệ biogas được áp dụng phổ biến ở các hộ nuôi bò sữa, chiếm 85,7\% số hộ có hầm ủ biogas. Sự hiểu biết về công nghệ biogas của các hộ chăn nuôi còn khá giới hạn, chỉ 23,3\% hộ dân được phỏng vấn biết về công nghệ biogas, 47,5\% hộ biết it về công nghệ này, trong khi 29,2\% hộ dân hoàn toàn không biết. Dựa trên số lượng đàn bò thịt trong vùng khảo sát, có thể tính được lượng $\mathrm{CH}_{4}$ phát thải hàng năm từ chất thải chăn nuôi là 252,3 tấn, 61,4 tấn, 8,2 tấn và 2,5 tấn từ các địa phương Sóc Trăng, Trà Vinh, Cần Thơ, và Hậu Giang.
\end{abstract}

Keywords: cow raising, greenhouse gas emission, the Mekong Delta, waste treatment

\section{Background}

As a result of the on-going industrialization in the country, the economy and society of the Mekong Delta (MD) of Viet Nam has been transformed fundamentally. Due to the natural advantage of a delta, the MD is famous for agricultural production such as rice cropping, fishery, animal husbandry, and poultry. Over $80 \%$ of the population of the MD is engaged in agricultural production, of which livestock production accounts for $30 \%$ of the total agricultural output for domestic consumption and export (GSO, 2015). The development of agriculture in the MD ensures the national food security, contributing to the local economic development and poverty reduction. Particularly, one main subarea that is accounting for a large proportion of the regional economy is cow-raising. This activity has brought high economic profit for livestock farmers with increasing number of cow nowadays (Le Thanh Hai, 2008). Although the benefit of cow industry is obvious, the problem of waste, which has not been properly taken into consideration, may cause environmental problems (Luu Huu Manh et al., 2009).

Matthews (2006) acknowledges that livestock production is seen as a major polluting cause, even greater than 
polluting transportation. Global livestock waste generates $65 \%$ of $\mathrm{N}_{2} \mathrm{O}$ in the atmosphere. This gas is capable of absorbing 296 times more energy than $\mathrm{CO}_{2}$. Domestic animals also emit $9 \%$ of global $\mathrm{CO}_{2}, 37 \%$ of $\mathrm{CH}_{4}$, which is 23 times more likely to retain heat than $\mathrm{CO}_{2}$. Animal husbandry additionally, contributes to $64 \%$ of $\mathrm{NH}_{3}$ - the culprit of acid rain. This means that animal husbandry is a major contributor to increasing greenhouse gases and its effects including acid rain.

Contamination of animal waste also entails several other factors that make the human and livestock environment unstable in the future. The accumulation of cow excrement from livestock poses a risk of water pollution (eutrophication, flora and fauna changes), effects odours, and impacts and threats to human health (Penakalapati et al., 2017). In the MD, biogas technology has been introduced as an effective method of treating animal waste, minimizing the risk of contamination from livestock production, and producing biogas for energy purposes (Vo et al., 2012). There were several projects supporting biogas installation undertaken in the MD such as the Biogas Program for the Animal Husbandry Sector in Vietnam, the Farm Household Biogas Project Contributing to Rural Development in Can Tho City, the Sustainable production of waste rice straw, etc.

Mekong Delta spent 1 million ton of fuel diesel for key agricultural production systems in 2016, and this number increases to 1.1 million ton in 2020 (Tin et al., 2016), which otherwise, by using biogas digesters, could be saved. Application of biogas digesters may raise local people's standard of living, as well as reduce the odour from animal husbandry activities, and avoid the complaint from neighbouring families (Nguyen Vo Chau Ngan, 2012). Biogas energy can simultaneously meet the demand for electricity for lighting and can supply fuel for livestock households. Therefore, this study focuses on the current status of waste treatment and risk of greenhouse gas emissions due to cattle raising in the MD.

\section{Methodology}

\subsection{Object of study}

The study was conducted in (i) Can Tho city, (ii) Hau Giang Province, (iii) Soc Trang Province, and (iv) Tra Vinh Province, where cattle raising is much popular compared to other provinces in the MD. Random and direct interviews were conducted with 120 cattle raising households. The survey was taken in the following areas:

(i) In Can Tho city, the survey was conducted in Binh Thuy district, Thot Not district, Phong Dien town, and Co Do town.

(ii) In Hau Giang province, the survey was conducted in Chau Thanh town, Phung Hiep town, and Long My town. (iii) In Soc Trang province, the survey was conducted in My Xuyen town and Tran De town.

(iv) In Tra Vinh province, the survey was conducted in Cau Ke town, Tra Cu town, and Chau Thanh town.

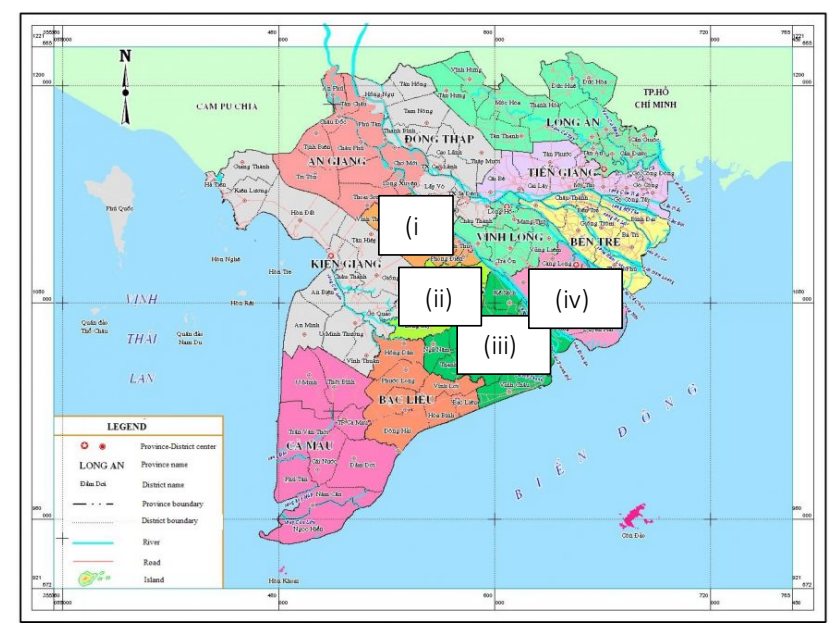

Figure 1. The MD map with four selected provinces

\subsection{Field survey}

The target group of the questionnaire was cattle raising farmers. It contains a combination of closed and openended questions. A testing phase was performed in 5 households to evaluate the questions, eliminate the inappropriate ones and made the correspondent modifications.

Formal interviews were conducted at randomly selected households in the areas of study enlisted previously, through the introduction of local authorities, heads of cooperatives and local people.

\subsection{Method of calculating the data}

\subsection{1 $\mathrm{CH}_{4}$ emissions from waste management activities}

In this study, the results of the study and calculations were based on the methodology of the IPCC (2006) report 4 Tier 1 and $2 . \mathrm{CH}_{4}$ gas in livestock production was taken from two sources - (i) digestion of food, and (ii) digestion of waste. Within the scope of the study, only $\mathrm{CH}_{4}$ emission from cattle waste was estimated.

The cows surveyed were divided into 3 groups - (i) 6 months old, (ii) 12 months old, and (iii) 18 months old with dairy cows, beef cows, and calves. According to the IPCC (2006), total $\mathrm{CH}_{4}$ emission from the cattle excrement was calculated by the formula [1]:

Total $\mathrm{CH}_{4 \text { manure }}=\sum_{(\mathrm{T})} \frac{\mathrm{EF}_{(\mathrm{T})} \times \mathrm{N}_{(\mathrm{T})}}{10^{6}}$

in which 
$\mathrm{CH} 4$ manure: total $\mathrm{CH}_{4}$ emissions from cattle's waste ( $\mathrm{Gg} \mathrm{CH}$ /year)

$\mathrm{EF}(\mathrm{T})$ : emission factor for each cattle group $\left(\mathrm{kg} \mathrm{CH}_{4}{ }^{*}\right.$ $\operatorname{cow}^{-1} *$ year $^{-1}$ )

$N(T)$ : number of individuals for each cow group

There were two options to calculate emission factor $E_{(T)}$ from cattle's digestive activities. This study worked with both options and compared the results.

a) Option 1: Using alternative data to the one from IPCC

The $\mathrm{CH}_{4}$ emission factor from waste depends on two main issues: the nature of the waste and the characteristics of the waste management system. According to IPCC (2006), the emission factor $\mathrm{EF}_{(\mathrm{T})}$ using the estimates of the manure managed per waste system within each climate region is calculated by the formula [2]:

$\mathrm{EF}_{(\mathrm{T})}=\mathrm{VS}_{(\mathrm{T})} \times 365 \times$
$\times\left[\mathrm{B}_{\mathrm{O}(\mathrm{T})} \times 0.67 \times \sum_{(\mathrm{S}, \mathrm{K})} \frac{\mathrm{MCF}_{(\mathrm{S}, \mathrm{K})}}{100} \times \mathrm{MS}_{(\mathrm{T}, \mathrm{S}, \mathrm{K})}\right]$

in which

MS: the rate of the used waste management (\%) depended on the waste management system.

$B_{0}$ : the highest methane yield $\left(\mathrm{m}^{3} \mathrm{CH}_{4} / \mathrm{kg}\right)$. The value for Asia region is shown in Table 1.

Table 1. Highest methane yield $\left(B_{0}\right)$

\begin{tabular}{lc} 
Cow groups & $\mathrm{B}_{\mathrm{o}}\left(\mathrm{m}^{3} \mathrm{CH}_{4} / \mathrm{kg}\right)$ \\
\hline Dairy cows & 0,13 \\
Meat cows & 0,1 \\
(Source: Safley et al., 1992) &
\end{tabular}

MCF: methane conversion factor (\%) which depends on the waste management system and the temperature of the area, see Table 2.

\section{Table 2. Methane conversion factor (MCF)}

\begin{tabular}{|c|c|c|c|c|c|}
\hline \multirow[b]{2}{*}{ No. } & \multirow[b]{2}{*}{ Waste management system } & & \multicolumn{3}{|c|}{ Methane conversion factor - MCF (\%) } \\
\hline & & & 26 & 27 & $\geq 28$ \\
\hline 1 & Lawn (not collect) & & 2 & 2 & 2 \\
\hline 2 & Daily collection to make fertilizer & & 1 & 1 & 1 \\
\hline 3 & Solid storage - Heap (over several mont & & 5 & 5 & 5 \\
\hline 4 & Grazing in the large fence, periodic colle & & 2 & 2 & 2 \\
\hline \multirow[t]{2}{*}{5} & Collecting and storing in liquid lagoons & natural hard board & 44 & 48 & 50 \\
\hline & (adding more water) & without hard natural board & 71 & 78 & 80 \\
\hline 6 & Pond storage (water for watering plants & reatment) & 79 & 80 & 80 \\
\hline \multirow[t]{2}{*}{7} & Storing pit under stalls & $<1$ month & 30 & 30 & 30 \\
\hline & & $>1$ month & 71 & 78 & 80 \\
\hline 8 & Dealing with biogas technology & & 10 & 10 & 10 \\
\hline
\end{tabular}

(Source: IPCC, 2006)

VS: volatile solids ( $\mathrm{kg} /$ day) calculated by a suggestion from IPCC (2006)

$V S=\left[G E \times\left(1-\frac{D E \%}{100}\right)+(U E \times G E)\right] \times\left(\frac{1-\mathrm{ASH}}{18.45}\right)$

with

- GE: total absorbed energy (MJ/day)

- UExGE: energy to convert into wastewater. The 0.04GE value was applied to most ruminants (except for those fed with grain foods, which account for more than $85 \%$ of the diet, the value was $0.02 \mathrm{GE}$ )

- ASH: the ash content of manure calculated as a fraction of the dry matter feed intake (value of 0.29 for cattle as result from the previous study of Sweeten et al., 1986)

- 18.45: total absorbed energy conversion coefficient GE per kg dry matter (MJ/kg)

- DE: digestible energy (\%), based on Table 3

\section{Table 3. Digestible energy DE}

Kind of food

Nutritious food

DE (\%)

Fresh grass

$75-85$

Poor nutrition (straw, hay)

$45-55$

The formula calculated the total absorbed energy (GE):

$G E \frac{\frac{N E_{m}+N E_{a}+N E_{l}+N E_{\text {work }}+N E_{p}}{R E M}+\frac{N E_{g}}{R E G}}{\frac{D E \%}{100}}$

GE depends on the following components:

Net energy for maintenance $\mathrm{NE}_{\mathrm{m}}$ (MJ/day):

$N E_{m}=C f_{i} \times$ weight $^{0.75}$

in which 
weight: live-weight of the cow $(\mathrm{kg})$

$\mathrm{Cf}_{\mathrm{i}}$ : coefficient which varies for each animal category $\left(\mathrm{MJ}^{*} \mathrm{day}^{-1} * \mathrm{~kg}^{-1}\right)$ which based on Table 4

\section{Table. 4 Coefficient $\mathrm{Cf}_{\mathrm{i}}$}

Group

Dairy cows $\mathrm{Cf}_{\mathrm{i}}\left(\mathrm{MJ}^{*} \mathrm{day}^{-1} * \mathrm{~kg}^{-1}\right)$

Female meat cows

0.386

Male meat cows

0.322

(Source: NRC, 1996)

- Net energy for activity $\mathrm{NE}_{\mathrm{a}}$ (MJ/day):

$$
N E_{a}=C_{a} \times N E_{m}
$$

in which

$\mathrm{NE}_{\mathrm{m}}$ : net energy for maintenance (MJ/day)

$C_{a}$ : the activity coefficient, corresponding to the animal's feeding situation, is shown in Table 5.

\section{Table 5. Activity coefficient $C_{a}$}

\begin{tabular}{lc} 
Activity status & $\mathrm{C}_{\mathrm{a}}$ \\
\hline Complete captivity & 0 \\
Grazing supplemented with food & 0.17 \\
Wide grazing area & 0.36
\end{tabular}

- According to NCR (1996), the energy for development $\mathrm{NE}_{\mathrm{g}}(\mathrm{MJ} /$ day) was calculated based on:

$$
\mathrm{NE}_{\mathrm{g}}=22.02 \times\left(\frac{\mathrm{BW}}{\mathrm{C} \times \mathrm{MW}}\right)^{0.75} \times \mathrm{WG}^{1.097}
$$

in which

BW: average individual weight $(\mathrm{kg})$

C: the coefficient is 0.8 for female cows and 1.2 for male cows

MW: average weight of female cows in the herd $(\mathrm{kg})$

WG: average daily gain $(\mathrm{kg} / \mathrm{day})$

- For cattle and buffalo, the net energy for lactation $N_{1}$ (MJ/day) is expressed as a function of the amount of milk produced, and its fat content expressed as a percentage (e.g. 4\%) (NRC, 2001):

$N E_{1}=$ Milk $\times(1.47+0.4 \times$ Fat $)$

in which

Milk: the amount of milk produced per day (kg/day)

Fat: fatness of milk (\%), Fat $=3.8 \%$

- $N E_{\text {work }}(\mathrm{MJ} /$ day) is energy for work. According to Bamualim \& Kartiarso (1985), about $10 \%$ of a day's $N E_{m}$ is required per hour for typical work for draft animals. This value is used as follows:

$$
N E_{\text {work }}=0.1 \times N E_{m} \times \text { Hours }
$$

in which

$\mathrm{NE}_{\mathrm{m}}$ : energy needed to sustain life ( $\mathrm{MJ} /$ day)
Hours: number of hours of daily work (hours)

- $\quad N E_{p}(M J / d a y)$ is energy for pregnancy. For cattle and buffalo, the total energy requirement for pregnancy for a 281-day gestation period averaged over an entire year is calculated as $10 \%$ of $N E_{m}$ (NRC, 1996).

$\mathrm{NE}_{\mathrm{p}}=0.1 \times N E_{\mathrm{m}}$

- REM - the ratio of net energy available in the diet for maintenance to digestible energy consumed. For cattle, REM is estimated using the following equation (Gibbs \& Johnson, 1993):

$$
\begin{aligned}
\text { REM }= & 1.123-\left(4.092 \times 10^{-3} \times \mathrm{DE} \%\right)+ \\
& +\left[1.126 \times 10^{-5} \times(\mathrm{DE} \%)^{2}\right]-\frac{25.4}{\mathrm{DE} \%}
\end{aligned}
$$

- $\quad$ REG - the ratio of net energy available for growth in a diet to digestible energy consumed. For cattle, REG is estimated using the following equation (Gibbs \& Johnson, 1993):

$$
\begin{aligned}
\text { REG }= & 1.164-\left(5.16 \times 10^{-3} \times \mathrm{DE} \%\right)+ \\
& +\left[1.308 \times 10^{-5} \times(\mathrm{DE} \%)^{2}\right]-\frac{37.4}{\mathrm{DE} \%}
\end{aligned}
$$

\section{b) Option 2: Using IPCC available data (2006)}

This option uses the $\mathrm{CH}_{4}$ emission factor according to the annual average temperature described by the IPCC for Asia.

Table $6 \mathrm{CH}_{4}$ emission factor for Asia

Type

Dairy cows

Cows

\begin{tabular}{ccc}
\multicolumn{3}{c}{$\begin{array}{c}\mathrm{CH}_{4} \text { emission factor } \\
\left(\mathrm{kg} \mathrm{CH}_{4}{ }^{*} \mathrm{Cow}^{-1} * \text { year }^{-1}\right)\end{array}$} \\
\hline $26^{\circ} \mathrm{C}$ & $27^{\circ} \mathrm{C}$ & $\geq 28^{\circ} \mathrm{C}$ \\
\hline 28 & 31 & 31 \\
1 & 1 & 1
\end{tabular}

(Source: IPCC, 2006)

\subsubsection{Data collecting}

Collected data for calculations are presented in Table 7.

\section{Table 7. Data needed to be collected}

Data Units

Number of individual of each group:

- Dairy cows: male, female

living being

- Cows: male, female

- Calves

Average weight of each group

Daily weight gain

The amount of milk produced per day

Hours of daily work

Daily amount of food

Type of food (rich in nutrients, fresh grass,

poor nutrition...)

How to collect and treat the excrement 


\begin{tabular}{lc} 
Data & Units \\
\hline Daily amount of waste & $\mathrm{kg}^{*}{ }_{\substack{\text { living being } \\
\\
{ }^{*} \text { day }^{-1}}}$
\end{tabular}

Cattle raising mode

\subsubsection{Data processing}

Microsoft Excel 2007 was used to analyze and process the survey data.

\section{Results and discussion}

\subsection{General assessment of the current status and methods of waste treatment}

\subsubsection{Summary of interviewed households}

To conduct the survey of the current status and methods of waste treatment in cattle raising in the MD, randomly households for interviews were selected. A total of 120 households were set up for interviews in the four areas. The detail of the distribution of the cattle farmer households is shown in Table 8.

Table 8. Type of cows distribution at each interviewed cow households

\begin{tabular}{lcccc} 
Type of cows & Can Tho & $\begin{array}{c}\text { Hau } \\
\text { Giang }\end{array}$ & $\begin{array}{c}\text { Soc } \\
\text { Trang }\end{array}$ & Tra Vinh \\
\hline Dairy cows & 10 & 0 & 22 & 0 \\
Beef cows & 19 & 30 & 5 & 30 \\
$\begin{array}{l}\text { Dairy cows and } \\
\text { beef cows }\end{array}$ & 1 & 0 & 3 & 0 \\
Total & 30 & 30 & 30 & 30
\end{tabular}

The households interviewed mostly contained stalls (98.3\%), the rest had no stalls. Regarding raising modes, "keeping cattle completely in stalls" accounted for 91.7\% and "grazing behind fences with food supplementation" accounted for a small ratio of $8.3 \%$. Detail of the number of cattle in the surveyed households is shown in Figure 2.

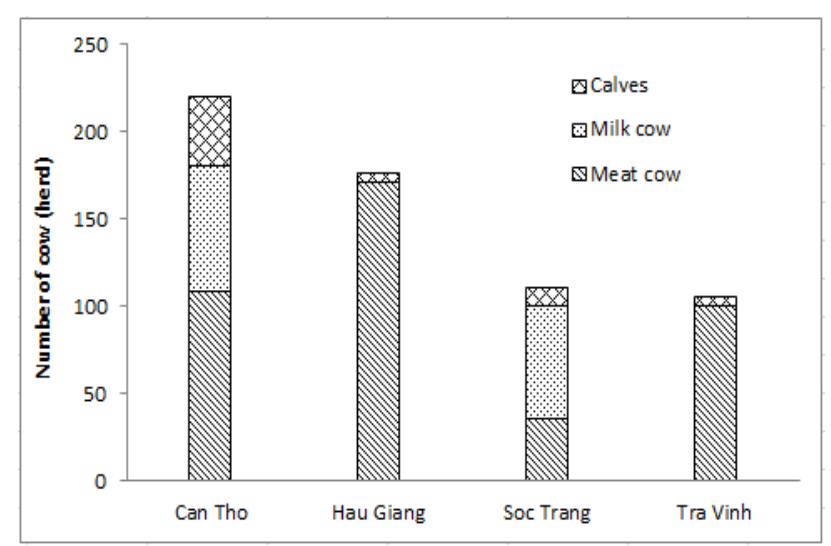

Figure 2 Distribution of cows in the surveyed areas

The interviewed households in Can Tho city have the highest number of cattle (220 in total); in Tra Vinh province they have the lowest number of cows (106 in totals) among the four surveyed provinces/cities. However, ac- cording to the GSO (2015), among the four areas, Tra Vinh was the province that had the highest number of cows (131.4 thousand cows), then Soc Trang was ranked second (24.7 thousand cows), Can Tho city was the third (3,500 cows), and Hau Giang (1,3 thousand cows) was ranked fourth. Throughout the survey, the number of cows in cities/provinces was largely different, due to the scale of production. The households in Can Tho city raised cattle in an intensive farming way. Most of them were well-off households with a large investment, and additionally, they received the support of local authorities. Therefore, they could raise several cattle; on average there were 7 cows per household. The households in Tra Vinh and Soc Trang raised cattle spontaneously on small scale, with an average of 4 cows per household. Finally, the households in Hau Giang had an average of 6 cows per household.

As mentioned above, there was a difference between the survey results and data collected in Soc Trang and Can Tho due to production scale. The survey of the dairy cow raising households in Can Tho city indicated that there were $36 \%$ households breeding from 3 to 5 cows, $38 \%$ households breeding 8 cows, $0.9 \%$ households breeding 9 cows, 30\% households breeding over 10 cows, and especially only one household breeding 31 dairy cows (including calves). The survey in Soc Trang showed that the households raised dairy cows on a small scale, mostly from 1 to 3 cows, and the highest number of cows raised in households was 6 cows.

The MD has advantageous conditions for raising dairy cows. There is a large dairy factory located in Can Tho city called "Vinamilk Dairy Factory". This is the first determinant of dairy cows development in the region. The biggest dairy development area, however, is within a radius of $100-120 \mathrm{~km}$ from the factory. When cattle raising places are situated more than $120 \mathrm{~km}$ from dairy factories, it is difficult to transport fresh milk from the farms to the factories. If the development of dairy cattle is too dispersed, the dairy cow-raising households that are too far away from milk collection stations will be impossible to guarantee milk quality at delivery. This may lead to a reduction in price and quality. The ideal distance between dairy cow-raising households and the dairy factories is up to $5 \mathrm{~km}$ far away to deliver fresh milk to the stations within an hour. Therefore, in each region, it is necessary to set up stations with freezing containers to collect milk. Soc Trang province and Can Tho city have built milk transit stations. 


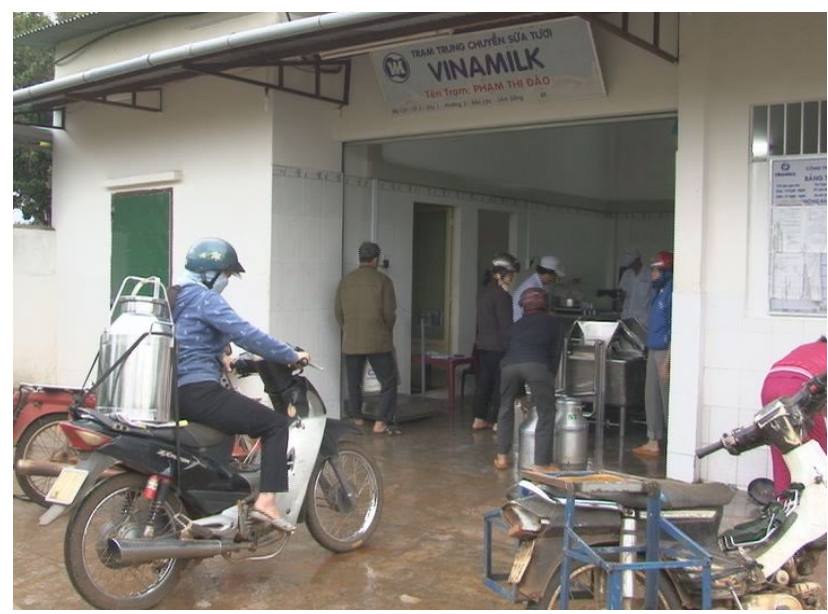

Figure 3. Milk transit station of Vinamilk company

(Source: Anh Dao)

At the same time, the MD had an abundant source of remains of agricultural activities such as corn stalks, sugar cane tops, pineapple peels, bean rinds, beer processing byproducts. These are considered valuable sources of food on the spot because most of dairy cow-raising households know how to take advantages of them. However, local farmers need capital to invest in cattle raising such as purchasing dairy cow breed (around US\$ 680 - 910/cow), building stalls, hiring fertilization and veterinary services (estimated of US\$ $1.0-1.2 / \mathrm{kg}$ of meat cow/month, or US\$7.5 - 8.0/kg of dairy cow/month). Local authorities offer credit loans to support dairy cow raising development in Can Tho and Soc Trang. This is a leverage factor that helps raise the possibility of growing dairy herds. Therefore, Can Tho city and Soc Trang province have better financial conditions for raising dairy cows compared to Hau Giang and Tra Vinh province.

\subsubsection{Situation of waste disposals}

\section{a) General situation}

Detailed information about the current situation of cattle waste treatment at the surveyed households can be summarized as follow:

In Can Tho city: according to the survey, 20\% of households built biogas tanks, $3.3 \%$ of households set up the biogas bags, $76.7 \%$ of households did not use biogas technology. Of which, one surveyed household used the biogas bag for 3 months. Due to the inadequate storage, the bag was perforated, and there were no repairers nearby in this area, so the households did not use it any longer. Hau Giang Province: according to the survey results, none of the households uses biogas digester for waste treatment. One household used to have a biogas bag but due to careless preservation, it was damaged and not able to be repaired. Nevertheless, the owner had a plan to build a brick biogas digester in the future for longer usage. In Soc Trang province: the survey showed that there were no biogas digesters being used by any cattle raising households. In Tra Vinh province: according to the total number of households investigated, 100\% did not have any biogas digesters to treat cattle excrement. It was notable that only three households added pig excrement to a composting bag, but no cow excrement.

Table 9. Current status of cattle waste treatment at the surveyed households

\begin{tabular}{|c|c|c|c|c|c|}
\hline Current status & Total & Can Tho & Hau Giang & Soc Trang & Tra Vinh \\
\hline Use biogas tanks & 6 & 6 & & & \\
\hline Use biogas bags & 1 & 1 & & & \\
\hline Digester bags damaged & 2 & 1 & 1 & & \\
\hline $\begin{array}{l}\text { Not apply biogas technology (no } \\
\text { biogas or not use cow excrement for } \\
\text { added material) }\end{array}$ & 111 & 22 & 29 & 30 & $\begin{array}{c}30 \text { (3 households adding pig } \\
\text { dung to the digesters, no cow } \\
\text { dung) }\end{array}$ \\
\hline Totals & 120 & 30 & 30 & 30 & 30 \\
\hline
\end{tabular}

In general, the percentage of households treating cattle excrement by using biogas in all three surveyed areas is limited (5.8\%). The rest of the households discharge excrement directly into the environment, which negatively affects the surface water, underground water, and surrounding air.

\section{b) Information about biogas technology}

Among 120 surveyed households, 35 households had no knowledge of biogas technology, 57 households had a little knowledge, and 28 households knew biogas well. Although the number of surveyed households having knowledge of biogas technology is relatively high (accounting for $70.8 \%$ ), there is around half of the house- holds having limited knowledge of biogas technology and one third having no knowledge.

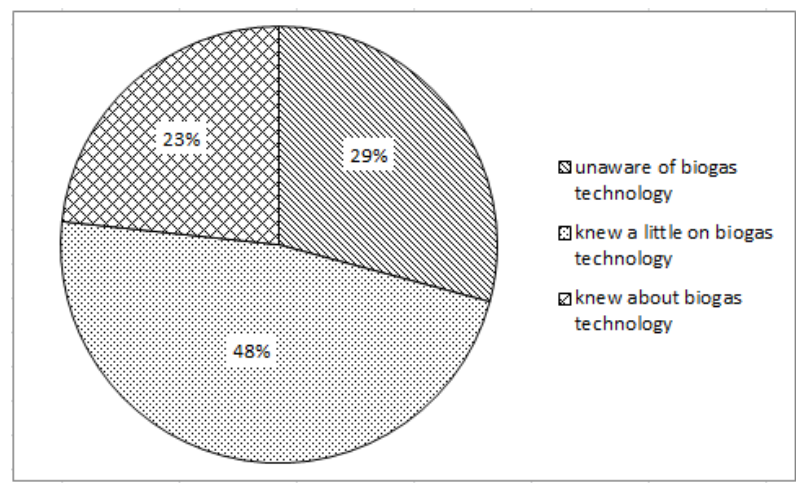

Figure 4 Extent of biogas understanding of the total surveyed households 
Almost half of the surveyed households, 47.5\%, got knowledge of biogas technology through media (television, books, and newspapers). However, their knowledge is limited and therefore, the farmers were not confident to use biogas digesters. On the other hand, $23.3 \%$ of the surveyed farmers knew the biogas technology via field observations or through the recommendation of the local authorities or of those who had used biogas technologies before. These last ones promote biogas digesters since they knew the benefits regarding cooking, lighting, sanitation, among others. However, these households could not afford the construction of biogas digesters due to financial reasons.

From the above-mentioned analysis, it is concluded that there are two main issues that obstacle the treatment of cow manure in biogas digesters: (i) lack of information and confidence, and (ii) economic reasons.

\section{2 $\mathrm{CH}_{4}$ emissions from waste management activities}

\subsection{1 $\mathrm{CH}_{4}$ emissions from waste management activities of livestock producers}

After gathering the results from the surveys and combining them with the calculations of emissions. Table 10 is obtained. This table shows that when calculating emission factor with the IPCC method, the $\mathrm{CH}_{4}$ value of the surveyed cows was higher than the $\mathrm{CH}_{4}$ value calculated with the HSPT method (in this study $3385 \mathrm{~kg}$ $\mathrm{CH}_{4} /$ year). There is a difference between the results of emission factor calculations according to the IPCC and according to this study. The emission factor of dairy cows in this study was about 10 times lower than that of the emission factor measured by the IPCC. The emission factor of beef cows, calculated accordingly to this study, is 1.92 times higher compared to the emission factor measured by the IPCC.

The main reason for the discrepancy depends mainly on the form of storing cow excrement and the rate of waste management used. In general, the cow excrement from the surveyed households was mainly stored in solid into piles (accounting for $80 \%$ ), in liquid lagoons (accounting for $6.7 \%)$, and in the form of scattering excrement over lawns (accounting for $4.2 \%$ ).

Table. $10 \mathrm{CH}_{4}$ emissions of cows surveyed according to the emission factor of the IPCC and this study

\begin{tabular}{|c|c|c|c|c|}
\hline \multirow[t]{2}{*}{ Cow group } & \multicolumn{2}{|c|}{ Emission factor by this study } & \multicolumn{2}{|c|}{ Emission factor by IPCC for Asia } \\
\hline & $\begin{array}{c}E F(T) \\
\left(k g ~ C H_{4}^{*} \operatorname{cow}^{-1} * \text { year }^{-1}\right)\end{array}$ & $\begin{array}{c}\text { Amount of emissions } \\
\left(\mathrm{kg} \mathrm{CH} \mathrm{CH}_{4} \text { /year }\right)\end{array}$ & $\begin{array}{c}E F \\
\left(\mathrm{~kg} \mathrm{CH}_{4}{ }^{*} \mathrm{cow}^{-1} * \text { year }^{-1}\right)\end{array}$ & $\begin{array}{c}\text { Amount of emissions } \\
\text { (kg } \mathrm{CH}_{4} / \text { year) }\end{array}$ \\
\hline Dairy cows & 3.04 & 440.67 & 31 & 4216 \\
\hline Meat cows & 1.92 & 744.59 & 1 & 416 \\
\hline Calves & 0.415 & 61.36 & - & - \\
\hline Totals & & 1246.6 & & 4632 \\
\hline
\end{tabular}

The results showed that most dairy cow-raising households mainly have the way of storing excrement in solid (96\% of dairy cow raising households), and the methane conversion factor of this system was about $5 \%$. Hence, an emission factor of the dairy cattle showed 10 timers lower value compared to the emission factor provided by the IPCC. This was due to the fact that countries in Asian region store about $40 \%$ of cow excrement in their liquid lagoons (Safley et al., 1992) and the methane conversion factor of this system is about $80 \%$.

On the contrary, the farmers raising beef cows largely store excrement in a liquid state, stickiness (in ponds, ditches, pits) and the methane conversion factor of this system is of about $80 \%$. At the same time, countries in Asian region let beef cows scatter excrement over pastures (about 50\%), or excrement was collected periodically (about 46\%) (Safley et al., 1992), and the methane emissions of these systems are about $2 \%$.

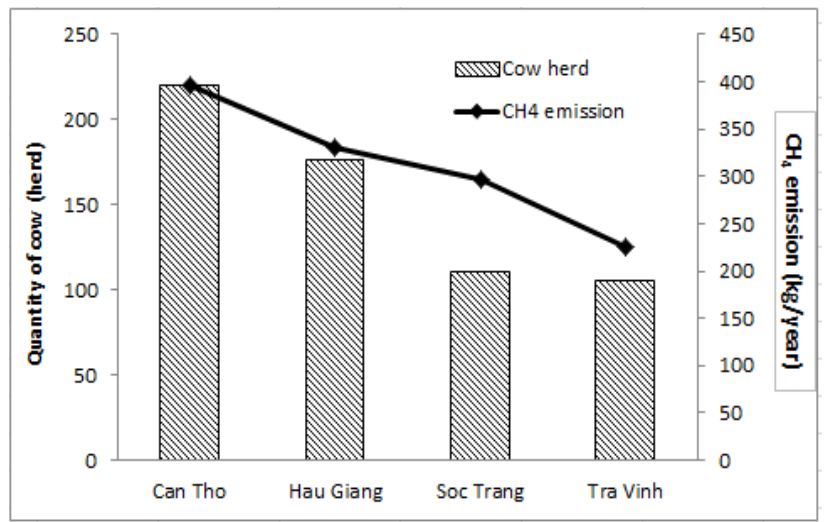

Figure 5. The amount of $\mathrm{CH}_{4}$ produced from the waste management activities according to the number of cows surveyed

In this study, the calculated emission factor of dairy cows was 1.6 times higher than the emission factor of beef cows. The reason for this difference was that the food for dairy cattle had a higher nutritional rate than the one for beef cattle (male and female. For male beef cows, as male cows are unable to have lactation and pregnancy, they 
were worth zero (total number of 239 male beef cows surveyed). A number of IPCC coefficients were used for this study, in which the coefficients for dairy cattle were higher in value than those of cattle for meat (the coefficient required for survival, the highest methane yield of excrement).

Using the calculation method for emission factor according to this study, the results of calculation of $\mathrm{CH}_{4}$ produced from waste management activities in the four surveyed provinces/cities are shown in Figure 5. As mentioned above, the cattle-raising households in Can Tho have the highest number of cows; thus, it has the highest amount of $\mathrm{CH}_{4}$ (395.8 $\mathrm{kg} \mathrm{CH} /$ year), Hau Giang has the second highest amount of $\mathrm{CH}_{4}$ (330.52 kg CH 4 /year), Tra Vinh with $171.34 \mathrm{~kg} \mathrm{CH}_{4}$ /year has the lowest amount of $\mathrm{CH}_{4}$ produced in four surveyed areas.

Tra Vinh and Soc Trang are two provinces with the same number of cows ( 5 cows different in balance), but $\mathrm{CH}_{4}$ is higher in Soc Trang than in Tra Vinh (71.38 $\mathrm{kg} \mathrm{CH}_{4} /$ year). The reason for this difference was that Soc Trang raised not only beef cows but also dairy cows, and as mentioned before, the emission factor in dairy cows is higher than that of beef cows. Therefore, despite of the same amount of cows, $\mathrm{CH}_{4}$ emissions are higher in Soc Trang than in Tra Vinh.

The quantities of $\mathrm{CH}_{4}$ produced per year from cow raising were double time comparing to the cow herds. However, in the case of dairy cows raising, the generated $\mathrm{CH}_{4}$ potential was much higher than the beef cows. The value does not include natural $\mathrm{CH}_{4}$ which releases from cow digestion itself. In case local people do not apply suitable methods to treat the waste, the generated $\mathrm{CH}_{4}$ will freely emit to the atmosphere, which strongly affects climate change conditions (Vac et al., 2013).

\subsection{2 $\mathrm{CH}_{4}$ produced from waste management according to statistic data at provinces/cities}

According to statistics of the GSO (2015), as Tra Vinh province had the highest number of beef cows (131.4 thousand herds of cows), it has also the highest amount of $\mathrm{CH}_{4}$ accounting 252.3 tons per year. Hau Giang is the province with the lowest number of cattle raised for meat among the 4 surveyed provinces ( 1.3 thousand herds of beef cows), and as a result, it contributes to the lowest amount of $\mathrm{CH}_{4}-2.5$ tons of $\mathrm{CH}_{4} /$ year, which is just $10 \%$ compared to Tra Vinh numbers (249.8 tons $\mathrm{CH}_{4} /$ year). Soc Trang province was the second province that had most abundant gases with 47.4 tons $\mathrm{CH}_{4} /$ year. Can Tho city was the third with 6.7 tons $\mathrm{CH}_{4}$ /year.

According to the GSO (2015), Tra Vinh and Hau Giang had few dairy cows, and the amount of $\mathrm{CH}_{4}$ produced was nearly zero. Soc Trang was the province with the highest number of dairy cows (4.6 thousand cows), and therefore, the highest amount of $\mathrm{CH}_{4}$ produced: 14 tons $\mathrm{CH}_{4} /$ year. Can Tho city produced $\mathrm{CH}_{4}$ emissions of 1.5 tons $\mathrm{CH}_{4} /$ year, the difference was 12.5 tons $\mathrm{CH}_{4}$ /year. Because of the high value of emission factor of dairy cows $(3.04 \mathrm{~kg}$ $\mathrm{CH}_{4}$ /cow/year), the amount of the produced $\mathrm{CH}_{4}$ was rather high (14 tons $\mathrm{CH}_{4}$ /year) even though, there were only 4.6 thousand cows in Soc Trang province. In conclusion, it can be seen that dairy cow-raising will produce a significant amount of greenhouse gas emissions.

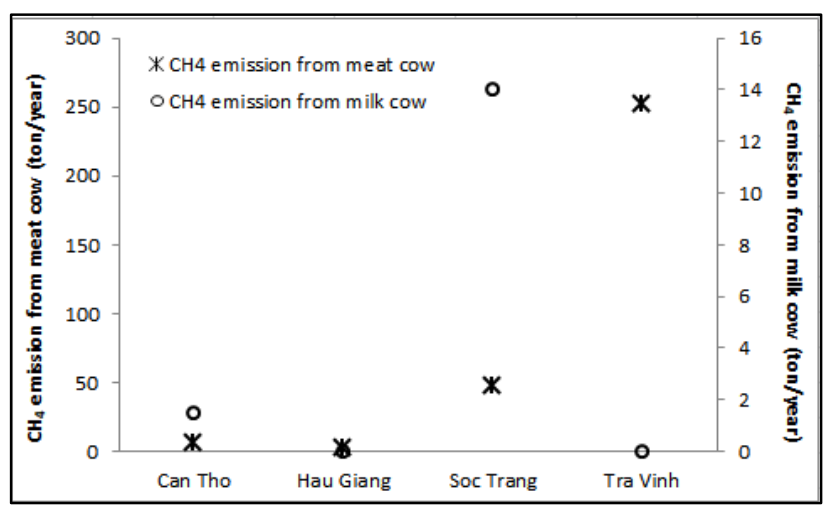

Figure 6. The amount of $\mathrm{CH}_{4}$ produced from waste management by meat cattle and dairy cattle

The total amount of the $\mathrm{CH}_{4}$ produced from waste management activities by dairy cows and beef cows is shown in Figure 6 . The amount of the $\mathrm{CH}_{4}$ produced from dairy cattle management was lower than that of cattle raised for meat, as according to the GSO (2015) the number of dairy cows was lower than that of beef cattle, of which the 2 provinces with few dairy cows were almost insignificant (Tra Vinh and Hau Giang).

Among the four provinces/cities, Tra Vinh was the province that had the highest total amount of $\mathrm{CH}_{4}$ emissions from the cattle waste management activities (dairy cows and beef cows) (252.3 tons $\mathrm{CH}_{4} /$ year), followed by Soc Trang with the $\mathrm{CH}_{4}$ emission was 61.4 tons $\mathrm{CH}_{4}$ /year, Can Tho city with 8.2 tons $\mathrm{CH}_{4}$ /year and Hau Giang with the lowest one of 2.5 tons $\mathrm{CH}_{4} /$ year.

\subsubsection{The $\mathrm{CH}_{4}$ emissions from waste management activities according to statistic data in the MD}

According to statistical data of the GSO (2015), within 13 provinces/city in the MD, the number of dairy cows was 16.3 thousand cows much lower (about 39.5 times) than the number of beef cattle (643.9 thousand cows). Thus, $\mathrm{CH}_{4}$ was produced from waste management activities of dairy cattle about 25 times lower than that of beef cattle. There was a difference between the cows' rate and the $\mathrm{CH}_{4}$ ratio of these two groups of cows (about 1.6 times). The difference was due to the fact that the emissions factor of dairy cows was 1.6 times higher than that of beef cows. 


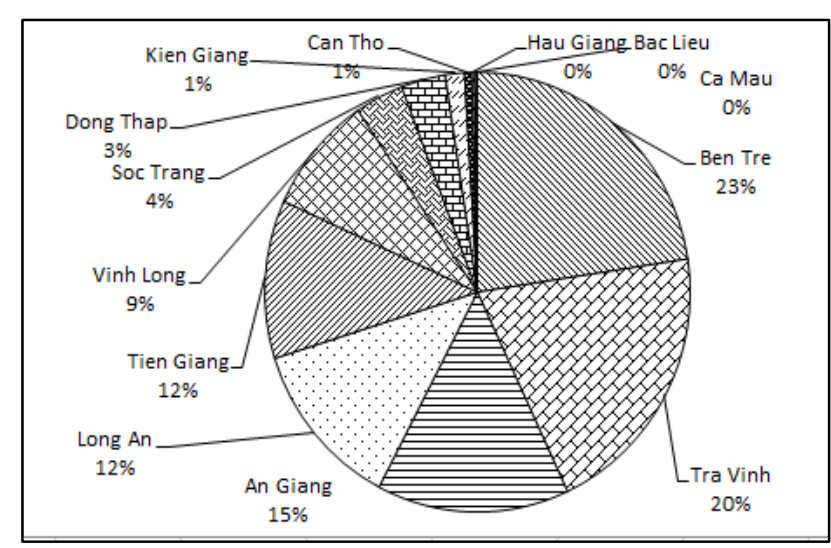

Figure 7. Number of cows by province in the MD

(Source: GSO, 2015)

The total $\mathrm{CH}_{4}$ emissions from beef cows accounted for 1236 tons/year and from dairy cows for 49.6 tons/year. Total $\mathrm{CH}_{4}$ emissions from waste cattle management activities (dairy and beef cows) in the MD are 1286 tons $\mathrm{CH}_{4}$ per year. This fact indicates that cow raising in particular and animal husbandry, in general, contributes substantially to the emission of greenhouse gases (especially $\mathrm{CH}_{4}$ ). According to the agriculture restructuring plan, the number of herds will grow strongly as 4.5 to 5.0\% per year up to 2020 (Prime Minister, 2017). Hence, the amount of $\mathrm{CH}_{4}$ emissions will increase that becomes an important issue to be solved to protect the environment.

A previous study by Nguyen Vo Chau Ngan et al. (2014) recorded that for those households with a large number of cattle, the amount of biogas produced will be excessive due to a large amount of excrement. When emissions exceed the requirement, farmers normally discharge such excessive gas into the air contributing to the greenhouse effect. Therefore, in addition to utilizing cow excrement for the operation of biogas digesters for only cooking purposes, the biogas produced should be used for other energy needs of households.

\section{Conclusions and recommendations}

\subsection{Conclusions}

As cattle-raising households in the surveyed provinces/cities of the MD mainly breed cattle at a small scale, local authorities have paid little attention to the problems caused by the animal's excrement. Despite abundant availability of excrement, the disposal safety is poor. Waste treatment is mainly concentrated on largescale farms, while small-scale farms freely discharge their waste.

Biogas technology is a waste treatment method that brings economic and environmental benefits. This technology has been applied in the MD for years, but it is not popular in the four surveyed provinces/cities of the MD. Households who built biogas tanks or installed biogas bags (accounting for $5.8 \%$ of the surveyed households) are highly environmentally conscious and wish to protect their health from environmental pollution.

One of the most important pollution created by livestock is $\mathrm{CH}_{4}$ emissions. With the characteristics of the cow herd in the MD in particular and in Vietnam in general, the emission factor of cattle waste in the surveyed provinces/cities differs from the emission factor proposed by IPCC for the Asian region. The emission factor of dairy cattle in this study was approximately 10 times lower than that of the emission factor calculated by the IPCC, the emission factor of beef cows in this study was 1.92 times higher than that of the emission factor calculated by the IPCC. This fact can be explained by the lack of countryspecific or technology-specific emission factors.

Biogas potential for lighting energy demand is an optimal solution for reducing greenhouse gas emissions from cow excrement. The biogas potential shows it is enough for lighting demand of $97.5 \%$ of all households. Thus, a biogas system is highly beneficiary to small-scale cattle raising farmers. The MD is an area of enormous potential for development of biogas digester. Effective treatment options such as the application of biogas technology in animal husbandry will open up opportunities to exploit a material source of cattle excrement for energy production and to make use of waste to decrease potential greenhouse gases emissions. However, the effectiveness and feasibility depend on the stable and sustainable development of cattle production, as well as the attention, direction and support policies of the central government and local governments, including economic incentives.

\subsection{Recommendations}

The central and local governments should pay more attention to small-scale cattle-raising farmers and make plans to inform local farmers of the benefits and application of biogas to encourage more local people to apply biogas systems at their households. Moreover, farmers can establish production cooperatives to share their biogas knowledge among co-operative members.

At present, the data required to calculate greenhouse gas emissions in cattle-raising in particular in animal husbandry, are not enough and are not collected systematically, especially the figures of the herd characteristics are not sufficient. Therefore, in order to improve inventory quality in the coming time, it is necessary to continue the survey and study to evaluate systematically and progressively to build more precise emissions factors.

Calculation results show that the methane conversion coefficient of the solid residue storage system in piles is much lower than that of sticky liquid storage in ponds. Therefore, in order to reduce the $\mathrm{CH}_{4}$ emissions from waste management, it is recommended that households 
store solid waste (waste in the lawn, daily waste collection or in the form of solid waste).

It is necessary to have the technology to utilize cow excrement in particular and animal waste in general for cooking and lighting purposes to avoid emission to the atmosphere.

\section{References}

[1] Bamualim A., Kartiarso (1985). Nutrition of draught animals with special reference to Indonesia. In: Draught Animal Power for Production. Copland J. W. (ed.). Australian Centre for International Agricultural Research (ACIAR), Proceedings Series No. 10. ACIAR, Canberra ACT, Australia.

[2] Gibbs M. J., Johnson D. E. (1993). Livestock emissions. In: International Methane Emissions, US Environmental Protection Agency, Climate Change Division. Washington DC, USA.

[3] GSO - General Statistical Office, 2015. Vietnam yearly statistic 2014. Statistical Publishing House.

[4] Hesse P. R. (1982). Storage and transport of biogas. Project field document No. 23. Food and agriculture organization of the United Nations, Rome.

[5] IPCC - Intergovernmental Panel on Climate Change (2006). Guidelines for national greenhouse gas inventories - Volume 4: Agriculture, forestry and other land use. Institute for Global Environmental Strategies, Japan.

[6] Le Thanh Hai (2008). Development of livestock and methods for sustainable production of pig raising. Accessed on http://www.vusta.vn/vi/news/Thong-tin -Su-kien-Thanh-tuu-KH-CN/Phat-trien-chan-nuoitrang-trai-va-mot-so-giai-phap-san-xuat-lon-hanghoa-ben-vung-27980.html.

[7] Luu Huu Manh, Bui Thi Le Minh, Nguyen Nhut Xuan Dung (2009). Evaluation of surface water pollution and efficiency of different treatment methods for pig waste water in smallholder production. Journal of Science of Can Tho University, Vol 12: 33-41.

[8] Matthews C. (2006). Livestock a major threat to the environment - Remedies urgently needed. Accessed on

http://www.fao.org/Newsroom/en/news/2006/100 0448/index.html.

[9] Nguyen Vo Chau Ngan (2012). Promotion of biogas plant application in the Mekong Delta of Vietnam. PhD dissertation, Technical University of Braun- schweig, Germany.

[10] Nguyen Vo Chau Ngan, Le Hoang Viet, Nguyen Truong Thanh, Nguyen Minh Hung, Huynh Thanh Hoai, Taro Izumi (2014). Evaluating gas emission from PE biogas digester in the Mekong Delta of Vietnam. Vietnam Journal of Science and Technology. Special issue on Environmental Protection Toward sustainable development 52(3A): 238-245.

[11] NRC - National Research Council (1996). Nutrient requirements of beef cattle. National Academy Press, Washington, DC, USA.

[12] NRC - National Research Council (2001). Nutrient requirements of dairy cattle, 7ed. National Academy Press, Washington, DC, USA.

[13] Penakalapati G., Swarthout J., Delahoy M. J., McAliley L., Wodnik B., Levy K., Freeman M. C. (2017). Exposure to Animal Feces and Human Health: A Systematic Review and Proposed Research Priorities. Environ Sci Technol 51(20): 11537-11552.

[14] Prime Minister (2017). Decision No. 1819/QĐ-TTg Approval for the agriculture restructuring plan 2017 - 2020.

[15] Safely L. M., Casada M. E., Woodbury J. W., Roos K. F. (1992). Global methane emissions from livestock and poultry manure. US Environmental Protection Agency, Global Change Division, Washington DC, EPA/400/1091/048.

[16] Sweeten J. M., Korenberg J., LePori W. A., Annamalai K., Parnell C. B. (1986). Combustion of cattle feedlot manure of energy production. Energy Agric. 5: 5572.

[17] Tin N. H., Hue B. T. B., Thuy T. L. K., Phuong T. L., Duyen C. M., Thinh H. C., Phuc H. N., 2016. Biodiesel production and use for agricultural production in the Mekong Delta: current status and potential. Can Tho University Journal of Science. Special issue: Renewable Energy: 80-91.

[18] Vac S. C., Popita G. E., Frunzeti N., Popovici A. (2013). Evaluation of greenhouse gas emission from animal manure using the closed chamber method for gas fluxes. Not Bot Horti Agrobo 41(2): 576-581.

[19] Vo Chau Ngan Nguyen, Trung Hieu Phan, Hoang Nam Vo (2012). Review on the most popular anaerobic digester models in the Mekong Delta. Journal of Vietnamese Environmental, Vol 2(1): 8-19. 